\title{
Phosphate-modified CpG oligonucleotides induce in vitro maturation of human myeloid dendritic cells
}

\author{
A.A. Ostanin ${ }^{1} \otimes$, O.Y. Leplina ${ }^{1}$, E.A. Burakova ${ }^{2,3}$, T.V. Tyrinova ${ }^{1,2}$, A.A. Fokina ${ }^{2,3}$, A.S. Proskurina ${ }^{3}$, \\ S.S. Bogachev ${ }^{3}$, D.A. Stetsenko ${ }^{2,3}$, E.R. Chernykh ${ }^{1}$ \\ ${ }^{1}$ Research Institute of Fundamental and Clinical Immunology, Novosibirsk, Russia \\ ${ }^{2}$ Novosibirsk State University, Novosibirsk, Russia \\ ${ }^{3}$ Institute of Cytology and Genetics of Siberian Branch of the Russian Academy of Sciences, Novosibirsk, Russia \\ @e-mail: ostanin62@mail.ru; ct_lab@mail.ru
}

\begin{abstract}
Myeloid dendritic cells (DCs) play an important role in the immune response; therefore, the search for compounds that can effectively activate DCs is a needful goal. This study was aimed to investigate the effect of synthetic CpG oligodeoxynucleotides (CpG-ODN) on the maturation and allostimulatory activity of myeloid DCs in comparison with other PAMP and DAMP molecules. For the research, we synthesized known CpG-ODN class C (SD-101 and D-SL03) containing thiophosphate internucleotide groups, and their original phosphate-modified analogues (SD-101M and $D$-SL03M) with mesylphosphoramide internucleotide groups ( $M=\mu$-modification). The effects of CpG-ODN and other activators were evaluated on DCs generated from blood monocytes in the presence of GM-CSF and IFN- $a$ (IFN-DC) or IL-4 (IL4-DC). Evaluation of the intracellular TLR-9 expression showed that both types of DCs (IFN-DC and IL4-DC) contained on average 52 and $80 \%$ of TLR-9-positive cells, respectively. The CpG-ODNs studied enhanced the allostimulatory activity of IFN-DCs, and the effect of $\mu$-modified CpG-ODNs was higher than that of CpG-ODNs with thiophosphate groups. The stimulating effect of CpG-ODN at a dose of $1.0 \mu \mathrm{g} / \mathrm{ml}$ was comparable (for D-SL03, D-SL03M, SD-101) with or exceeded (for SD-101M) the effect of LPS at a dose of $10 \mu \mathrm{g} / \mathrm{ml}$. At the same time, IFN-DCs were characterized by greater sensitivity to the action of CpG-ODNs than IL4-DCs. The enhancement of DC allostimulatory activity in the presence of CpG-ODNs was associated with the induction of final DC maturation, which was confirmed by a significant decrease in the number of CD14+DC, an increase in mature CD83+DC and a trend towards an increase in CD86+DC. Interestingly, the characteristic ability of LPS to enhance the expression of the co-stimulatory molecule OX40L on DCs was revealed only for the $\mu$-analogue SD-101M. In addition, CpG-ODNs (SD-101 and SD-101M) had a stimulatory effect on IFN- $\gamma$ production comparable to the action of LPS. The data obtained indicate a stimulating effect of CpG-ODN on the maturation and allostimulatory activity of human myeloid DCs, which is more pronounced for $\mu$-modified analogs. Key words: monocytes; dendritic cells; differentiation; maturation; PAMP- and DAMP-activators; allo-MLR; CpG-oligonucleotide.
\end{abstract}

For citation: Ostanin A.A., Leplina O.Y., Burakova E.A., Tyrinova T.V., Fokina A.A., Proskurina A.S., Bogachev S.S., Stetsenko D.A., Chernykh E.R. Phosphate-modified CpG oligonucleotides induce in vitro maturation of human myeloid dendritic cells. Vavilovskii Zhurnal Genetiki i Selektsii = Vavilov Journal of Genetics and Breeding. 2020;24(6):653-660. DOI 10.18699/VJ20.659

\section{CpG олигонуклеотиды с модифицированными фосфатными группами индуцируют созревание миелоидных дендритных клеток человека in vitro}

\author{
А.А. Останин ${ }^{1} \otimes$, О.Ю. Аеплина ${ }^{1}$, Е.А. Буракова ${ }^{2}, 3$, Т.В. Тыринова ${ }^{1,2}$, А.А. Фокина ${ }^{2,3}$, А.С. Проскурина ${ }^{3}$, \\ С.С. Богачев ${ }^{3}$, А.А. Стеценко ${ }^{2,3}$, Е.Р. Черных ${ }^{1}$

\footnotetext{
${ }^{1}$ Научно-исследовательский институт фундаментальной и клинической иммунологии, Новосибирск, Россия

${ }^{2}$ Новосибирский национальный исследовательский государственный университет, Новосибирск, Россия

${ }^{3}$ Федеральный исследовательский центр Институт цитологии и генетики Сибирского отделения Российской академии наук, Новосибирск, Россия 凶e-mail: ostanin62@mail.ru; ct_lab@mail.ru
}

\begin{abstract}
Аннотация. Миелоидные дендритные клетки (ДК) играют важную роль в иммунном ответе, поэтому актуальной задачей является поиск соединений, способных эффективно активировать ДК. Целью настоящей работы было изучение влияния синтетических CpG олигодезоксинуклеотидов (CpG-ODN) на созревание и аллостимуляторную активность миелоидных ДК в сравнении с другими РАMP и DAMP молекулами. Для исследований были синтезированы CpG-ODN класса C (SD-101 и D-SL03), содержащие тиофосфатные межнуклеотидные группы, а также получены их оригинальные фосфат-модифицированные аналоги (SD-101M и D-SL03M) с мезилфосфорамидными межнуклеотидными группами (M = в культурах ДК, генерированных из моноцитов крови в присутствии GM-CSF и IFN-a (IFN-ДK) или IL-4 (IL4-ДK).
\end{abstract}




\begin{abstract}
Оценка внутриклеточной экспрессии TLR-9 показала, что оба типа ДК (IFN-ДК и IL4-ДК) содержали в среднем 52 и 80 \% TLR-9-позитивных клеток соответственно. Исследуемые CpG-ODN усиливали аллостимуляторную активность IFN-ДК, причем эффект н-модифицированных CpG-ODN был выше, чем тиофосфатных CpG-ODN. Стимулирующий эффект CpG-ODN в дозе 1.0 мкг/мл был сопоставим (для D-SL03, D-SL03M, SD-101) или превышал (для SD-101M) действие липополисахарида (LPS) в дозе 10 мкг/мл. При этом IFN-ДК характеризовались большей чувствительностью к действию CPG-ODN, чем IL4-ДК. Усиление аллостимуляторной активности ДК в присутствии CpG-ODN было связано с индукцией конечного созревания клеток, что подтверждалось значимым снижением количества CD14+ ДК, увеличением доли зрелых CD83+ ДК и тенденцией к возрастанию CD86+ ДК. Интересно, что характерная для LPS способность усиливать экспрессию костимуляторной молекулы OX40L на ДК была выявлена только для $\mu$-аналога SD-101M. Кроме того, CpG-ODN (SD-101 и SD-101M) оказывали стимулирующий эффект на продукцию IFN- $\gamma$, сопоставимый с действием LPS. Полученные в целом данные свидетельствуют о стимулирующем действии CpG-ODN на созревание и аллостимуляторную активность миелоидных ДК человека, которое более выражено для $\mu$-модифицированных аналогов.

Ключевые слова: моноциты; дендритные клетки; дифференцировка; созревание; PAMP- и DAMP-активаторы; алло-СКЛ; CpG-олигонуклеотид.
\end{abstract}

\section{Introduction}

Dendritic cells (DC) play an important role in immune responses, thus justifying their application as cellular targets and potential cellular modality for developing novel anti-cancer immunotherapies. Taking into account that only mature DC with high antigen-presenting and co-stimulatory molecule expression possess immunostimulatory activity (Banchereau et al., 2000), R\&D efforts toward discovery of novel molecular candidates capable of effectively activating DC and induce their maturation are clearly very topical.

Pathogen-associated molecular patterns (PAMP) and damage-associated molecular patterns (DAMP) released upon autologous cell damage belong to natural DC activators. PAMP-dependent effects are mediated via pattern-recognition receptors, while DAMP molecules are recognised by intracellular sensors and activate DC via secondary messengers, such as tumour-necrosis factor $\alpha$ (TNF- $\alpha$ ) (Jounai et al., 2013; Kawasaki, Kawai, 2014). The effects of various compounds on human DC are usually assessed in vitro in monocyte-derived DC cell cultures generated in the presence of GM-CSF/IL4 or GM-CSF/IFN- $\alpha$ (Cehim, Chies, 2019) cytokine combinations. In these settings, a Toll-like receptor 4 (TLR-4)-specific ligand, bacterial lipopolysaccharide (LPS), serves as a standard cell activator. However, LPS-associated pyrogenicity effectively prevents its clinical application.

Bacterial and viral DNA species are also capable of activating terminal DC maturation. This activity is accounted for by the presence of unmethylated $\mathrm{CpG}$-dinucleotides in their structure, which could be imitated by synthetic $\mathrm{CpG}$ oligodeoxynucleotides (CpG-ODN) that mediate downstream signalling via TLR-9 (Polovinkina, Markov, 2010). Synthetic CpG-ODN derivatives have demonstrated pronounced immunostimulatory and anti-cancer effects in vivo, and therefore these compounds are currently considered as perspective adjuvants in anti-cancer immunotherapy (Scheiermann, Klinman, 2014; Shirota, Klinman, 2014; Shirota et al., 2015). CpGODNs along with plasmacytoid DC have been shown to exert stimulatory effects on bone marrow-derived DC in murine experimental systems (Behboudi et al., 2000). Meanwhile, CpG-ODN-dependent sensitivity in humans is attributed mainly to plasmacytoid DC, while CpG-ODN-mediated effects on myeloid DC were addressed in just a few studies that produced rather contradictory results (Behboudi et al., 2000; Hoene et al., 2006).
This study aimed to assess the effects of CpG-ODN on maturation and allostimulatory activity of myeloid DC generated from blood monocytes in the presence of GM-CSF and IFN- $\alpha$ (IFN-DC) or IL-4 (IL4-DC) in comparison with other PAMP (LPS) and DAMP activators. Specifically, we assessed the effects of CpG-ODN class C derivatives SD-101 (Levy et al., 2016) and D-SL03 (Yang et al., 2013) with thiophosphate internucleotide groups, as well as original phosphate-modified analogues (SD-101M, D-SL03M) with mesyl-phosphoramidate internucleotide groups $(\mathrm{M}=\mu$-modification) (Chelobanov et al., 2017).

In addition, we analysed the effects of DAMP activators: double-stranded DNA (dsDNA) and a synthetic polycationic adjuvant azoximer bromide (AB) (Kabanov, 2004; Powell et al., 2015), which was shown to enhance antigen-presenting DC function via activating pro-inflammatory signalling pathways (Dyakonova et al., 2004).

\section{Materials and methods}

In this study the following compounds were synthesised, purified and characterised: $\mathrm{CpG}-\mathrm{ODN}$ class C: $\mathrm{SD}-101$ and D-SL03 containing thiophosphate (phosphorothioate) internucleotide groups, and original modified analogues (SD-101M, D-SL03M) with mesyl-phosphoramidate $(\mu)$ internucleotide linkages. CpG-ODN sequences used in this study are shown in Table 1.

DC were obtained from peripheral blood mononuclear cells (PBMC) isolated from heparinised venous blood of healthy donors using Ficoll-Verografin gradient centrifugation. IFN-DC were generated by cultivating an adherent PBMC fraction in Falcon (BD Biosciences, UK) flasks in RPMI-1640 medium (Sigma-Aldrich, St. Louis, MO, USA) supplemented with $0.3 \mathrm{mg} / \mathrm{ml}$ L-glutamine, $5 \mathrm{mM}$ HEPES-buffer, $100 \mu \mathrm{g} / \mathrm{ml}$ gentamycin and $5 \%$ foetal bovine serum (FBS) (BioloT, St. Petersburg, Russia) in the presence of GM-CSF (SigmaAldrich, $40 \mathrm{ng} / \mathrm{ml})$ and IFN-alpha (1000 U/ml, Roferon ${ }^{\circledR}$-A, Hoffmann-La Roche Ltd, Basel, Switzerland,) for 3 days with a subsequent maturation step in the presence of LPS (LPS E. coli 0114:B4, Sigma-Aldrich, $10 \mu \mathrm{g} / \mathrm{ml}$ ) for $48 \mathrm{~h}$.

IL4-DC were generated from an adherent PBMC fraction after incubation in full culture medium in the presence of GM-CSF (40 ng/ml, Sigma-Aldrich), IL-4 (40 ng/ml, SigmaAldrich) and $5 \%$ FBS for 5 days followed by an additional maturation step in the presence of LPS for $48 \mathrm{~h}$. In addition to 
Table 1. List of CpG-oligonucleotides (CpG-ODN)

\begin{tabular}{|c|c|c|c|c|}
\hline Name & Sequence $\left(5^{\prime}-3^{\prime}\right)$ & Size (bp) & $\begin{array}{l}\text { Internucleotide } \\
\text { group }\end{array}$ & CpG (yes/no) \\
\hline SD-101 & tcgaacgttcgaacgttcgaac:gttcgaat & 30 & PS & CpG \\
\hline SD-101M & tcgaacgttcgaacgttcgaac:gttcgaat & 30 & $\mu$ & CpG \\
\hline D-SL03 & tcgcgaacgttcgccgcgttc:gaacgcgg & 29 & PS & CpG \\
\hline D-SL03M & tcgcgaacgttcgccgcgttc:gaacgcgg & 29 & $\mu$ & CpG \\
\hline ODNcontrol & tgcaagcttgcaagcttgcaag:cttgcaat & 30 & $\mu$ & no \\
\hline
\end{tabular}

Note. CpG dinucleotides are shown in bold; palindromic sequences are underlined; a middle of the palindromic sequence is indicated with the colon. PS - thiophosphate group; $\mu$-mesylphosphoramide group.

different concentrations of CpG-ODNs, terminal DC maturation was also achieved by incubation with other activators azoximer bromide (AB, NPO Petrovaks Farm, Moscow, Russia) at $2 \mathrm{ng} / \mathrm{ml}$, and double-stranded DNA (dsDNA) at $5 \mu \mathrm{g} / \mathrm{ml}$.

Intracellular TLR-9 expression in immature DC was assessed in IFN-DC and IL4-DC populations on days 3 and 5, respectively. To this end, cells were permeabilised using a commercially available Fixation/Permeabilization Solution Kit (BD Cytofix/Cytoperm ${ }^{\mathrm{TM}}$, San Jose, CA, USA), according to the manufacturer's instructions. Cells were stained with allophycocyanin (APC)-labelled anti-TLR-9 antibodies (BD PharMingen, San Jose, CA, USA). Matching isotype antibodies labelled with an appropriate fluorochrome were used as negative controls. Percentages of TLR-9-positive DC were calculated based on 10000 events collected during flow cytometric analysis for each sample.

Stimulatory DC activity was assessed in allogeneic mixed leukocyte reactions (allo-MLR) using donor PBMC as responder cells cultivated in round-bottomed 96-well plates $\left(0.1 \times 10^{6} /\right.$ well $)$ in RPMI-1640 medium containing $10 \%$ inactivated $\mathrm{AB}$ (group IV) donor serum at $37^{\circ} \mathrm{C}$ in a $\mathrm{CO}_{2}$-incubator. DC used as stimulator cells were added at a ratio of $\mathrm{PBMC}: \mathrm{DC}=10: 1$. To assess proliferation, cells were incubated for 4 days, followed by pulse-labelling with $1.0 \mu \mathrm{Ci} /$ well of $[3 \mathrm{H}]$ thymidine for the last $18 \mathrm{~h}$.

To perform immunophenotyping of IFN-DC, cells were stained with phycoerythrin (PE)-labelled anti-CD14 (Sorbent, Moscow) or anti-OX40L (anti-CD252, BioLegend, San Diego, CA, USA), fluorescein isothiocyanate (FITC)-labelled antiCD83, anti-CD86 (BD PharMingen) and anti-HLA-DR (Sorbent), and analysed by flow cytometry (FACSCalibur, Becton Dickinson).

Cytokine (TNF- $\alpha$, IFN- $\gamma$ ) concentrations were measured in 5-day culture supernatants of IFN-DC by ELISA using commercially available kits (Vector-Best, Novosibirsk), according to the manufacturer's instructions.

Statistical analysis was performed using an analytics software portfolio Statistica 6.0 for Windows (StatSoft, USA). Data is presented as Median (Me) with the interquartile range (IQR, 25-75\% quartiles). Related samples were compared using a nonparametric paired difference test (Wilcoxon signed-rank test), and independent samples were analysed using Mann-Whitney U test; $p<0.05$ was considered statistically significant.

\section{Results}

The assessment of intracellular TLR-9 expression in freshly isolated blood monocytes derived from healthy donors and immature IFN-DC/IL4-DC generated after 3- and 5-days culture, respectively, showed that the proportion of TLR-9-positive cells in monocyte precursors and IL4-DC was at about $80 \%$ level (Fig. 1). In contrast, relative content of TLR-9+ cells in IFN-DC population was significantly lower ranging from 40 to $56 \%$ (Me $52.5 \%, p<0.05$ ). Nevertheless, the data obtained implies potential sensitivity of DC generated both in the presence of IL-4 and IFN-alpha to the stimulatory effects of CpG-ODN delivering maturation signals.

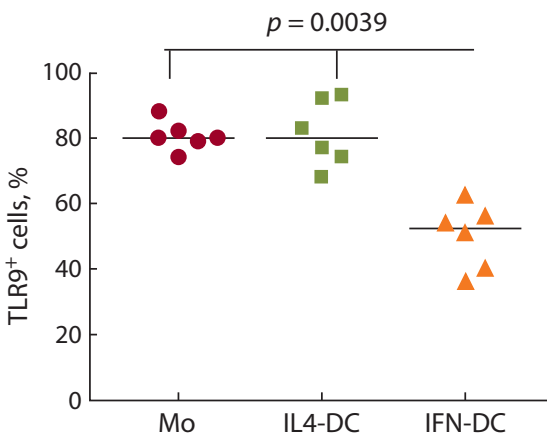

Fig. 1. Intracellular TLR-9 expression in monocytes and immature IL4-DC and IFN-DC of healthy donors $(n=6)$.

The data are presented as individual and median values; $p$ - Mann-Whitney U-test.

Therefore, in our next set of experiments we applied dilution series (from 0.5 to $5.0 \mu \mathrm{g} / \mathrm{ml}$ ) of CpG-ODN derivatives synthesised here to assess their effect on IFN-DC-mediated ability to stimulate $\mathrm{T}$ cell proliferative responses in allo-MLR. Indeed, allostimulatory DC activity is a distinct integral marker of an overall DC activity, being associated with the degree of DC maturation, HLA/co-stimulatory molecule expression, as well as the spectrum and levels of cytokines produced by DC. A "classical" PAMP-activator LPS (at $10 \mu \mathrm{g} / \mathrm{ml}$ ) was used as a positive control, while ODN with $\mu$-modifications, but lacking $\mathrm{CpG}$-dinucleotides (at $1 \mu \mathrm{g} / \mathrm{ml}$ ), was used as a negative control. Table 2 shows that LPS treatment caused nearly a 3-fold enhancement of allostimulatory DC activity. All CpG-ODN tested induced IFN-DC maturation, which manifested itself in a statistically significant enhancement of allostimulatory DC activity. In control experiments, 
Table 2. T cell proliferative response in allo-MLR and allostimulatory activity (FI) of IFN-DC generated with CpG-ODNs

\begin{tabular}{|c|c|c|c|c|c|c|}
\hline \multirow[t]{2}{*}{ Types of allo-MLR } & & \multirow[t]{2}{*}{ Control } & \multicolumn{4}{|l|}{ CpG-ODN } \\
\hline & & & $0.5 \mu \mathrm{g} / \mathrm{mL}$ & $1.0 \mu \mathrm{g} / \mathrm{mL}$ & $2.5 \mu \mathrm{g} / \mathrm{mL}$ & $5.0 \mu \mathrm{g} / \mathrm{mL}$ \\
\hline PBMC + immature DC & $\mathrm{cpm}$ & $2310(1630-2600)$ & & & & \\
\hline \multirow[t]{2}{*}{$\mathrm{PBMC}+\mathrm{DC}_{\text {ODNcontrol }}$} & $\mathrm{cpm}$ & $2350(2100-2500)$ & & & & \\
\hline & $\mathrm{FI}$ & $1.03(0.99-1.39)$ & & & & \\
\hline \multirow[t]{2}{*}{$\mathrm{PBMC}+\mathrm{DC}_{\mathrm{LPS}}$} & $\mathrm{cpm}$ & 7730 (5630-9620) & & & & \\
\hline & $\mathrm{FI}$ & $2.9(2.5-4.6)$ & & & & \\
\hline \multirow[t]{2}{*}{$\mathrm{PBMC}+\mathrm{DC}_{\mathrm{SD}-101}$} & $\mathrm{cpm}$ & & $5520(4650-11890)$ & $6550(3510-9650)$ & 7520 (4950-10380) & $6960(5830-10130)$ \\
\hline & $\mathrm{FI}$ & & $3.0(2.4-5.0)$ & $3.1(1.8-4.6)$ & $3.6(3.1-4.9)$ & $3.0(2.6-4.8)$ \\
\hline \multirow[t]{2}{*}{$\mathrm{PBMC}+\mathrm{DC}_{\mathrm{SD}-101 \mathrm{M}}$} & $\mathrm{cpm}$ & & 7680 (6450-14 170) & $9030(8010-12100)$ & 7520 (6030-13710) & $6530(6030-13700)$ \\
\hline & $\mathrm{FI}$ & & $4.6(3.0-6.7)^{* *}$ & $5.0(3.7-6.0)^{* *}$ & $4.5(2.8-6.5)^{*}$ & $4.2(2.7-6.1)$ \\
\hline \multirow[t]{2}{*}{$\mathrm{PBMC}+\mathrm{DC}_{\mathrm{D}-\mathrm{SL} 03}$} & $\mathrm{cpm}$ & & $3060(2290-10080)$ & $4660(3550-12960)$ & $4260(3200-11140)$ & $5180(3210-11460)$ \\
\hline & $\mathrm{FI}$ & & $1.6(1.2-4.8)$ & $2.4(1.5-5.3)$ & $2.4(1.5-5.3)$ & $2.5(2.0-4.8)$ \\
\hline \multirow[t]{2}{*}{$P B M C+D C_{D-S L 03 M}$} & $\mathrm{cpm}$ & & $5930(3380-11420)$ & $7210(5080-16060)$ & 6670 (4700-17 100) & $6000(3760-14150)$ \\
\hline & $\mathrm{FI}$ & & $2.5(1.6-5.4)^{* *}$ & $4.0(2.1-6.7)^{* *}$ & $3.7(2.0-7.7)^{* *}$ & $2.7(2.1-6.1)$ \\
\hline
\end{tabular}

Note. The data of two independent experiments $(n=8)$ are presented as median and interquartile range (in brackets); cpm - count per minute; $\mathrm{Fl}$ - index of influence. ${ }^{*} p<0.05 ;{ }^{* *} p<0.01$ - significant difference between $\mu$-CpG-ODN and PS-CpG-ODN (Wilcoxon's W test).

Table 3. T cell proliferative response in allo-MLR (cpm) and allostimulatory activity (FI) of IFN-DC and IL4-DC generated with different stimuli

\begin{tabular}{|c|c|c|c|}
\hline Types of allo-MLR & & IFN-DC & IL4-DC \\
\hline PBMC + immature DC & $\mathrm{cpm}$ & $2250(1900-2600)$ & $2720(2180-3080)$ \\
\hline \multirow[t]{2}{*}{$\mathrm{PBMC}+\mathrm{DC}_{\mathrm{ds} \mathrm{DNA}}$} & $\mathrm{cpm}$ & $5710(4810-8510)$ & $6070(4950-7100)$ \\
\hline & $\mathrm{FI}$ & $2.6(2.3-3.1)$ & $2.4(2.0-2.5)$ \\
\hline \multirow[t]{2}{*}{$\mathrm{PBMC}+\mathrm{DC}_{\mathrm{AB}}$} & $\mathrm{cpm}$ & $7350(6040-8160)$ & $4410(3880-5410)$ \\
\hline & $\mathrm{FI}$ & $2.8(2.4-3.7)$ & $1.7(1.5-2.0)$ \\
\hline \multirow[t]{2}{*}{$\mathrm{PBMC}+\mathrm{DC}_{\mathrm{SD}-101 \mathrm{M}}$} & $\mathrm{cpm}$ & 7900 (6090-9510) & 7200 (5460-8470) \\
\hline & $\mathrm{FI}$ & $3.3(2.9-5.0)$ & $2.6(2.5-2.8)$ \\
\hline \multirow[t]{2}{*}{$\mathrm{PBMC}+\mathrm{DC}_{\mathrm{D}-\mathrm{SL} 03 \mathrm{M}}$} & $\mathrm{cpm}$ & 7050 (5590-10560) & $5540(4420-7650)$ \\
\hline & $\mathrm{FI}$ & $3.2(2.6-4.6)$ & $2.0(1.8-2.7)$ \\
\hline
\end{tabular}

Note. The data of two independent experiments $(n=8)$ are presented as median and interquartile range (in brackets); cpm - count per minute; FI - index of influence. Stimuli: dsDNA $5 \mu \mathrm{g} / \mathrm{ml}$; AB $2 \mathrm{ng} / \mathrm{ml}$; SD-101M and D-SL03M $1 \mu \mathrm{g} / \mathrm{ml}$.

ODN lacking CpG motif did not affect functional DC activity in allo-MLR [fold increase (FI) = 1.03; IQR 0.99-1.39].

Characteristically, treatment with CpG-ODN containing mesyl-phosphoramidate ( $\mu$-) groups (SD-101M and D-SL03M) at $0.5,1.0$ and $2.5 \mu \mathrm{g} / \mathrm{ml}$ was significantly more effective $(p<0.01)$ in inducing terminal IFN-DC maturation, as compared to analogous $\mathrm{CpG}-\mathrm{ODN}$ that contained thiophosphate groups. Notably, SD-101M exerted the most pronounced effect in these experiments. Thus, SD-101M treatment at the minimal dose tested $(0.5 \mu \mathrm{g} / \mathrm{ml})$ induced clear DC maturation to a degree comparable to that observed in the presence of LPS at $10 \mu \mathrm{g} / \mathrm{ml}$, while the effectiveness of $\mu$-analogue SD-101 at $1.0 \mu \mathrm{g} / \mathrm{ml}$ was significantly higher than LPS $(p<0.05)$.
Next, we performed comparative studies of the effect of $\mu$-analogues CpG-ODN (SD-101M and D-SL03M) and DAMP activators (dsDNA, AB) on allostimulatory activity of two DC subsets (IFN-DC and IL4-DC). Table 3 shows that stimulatory effect of CpG-ODN $\mu$-analogues at $1 \mu \mathrm{g} / \mathrm{ml}$ on functional activity of IFN-DC and IL4-DC in allo-MLR was comparable to that displayed by dsDNA and AB. Furthermore, as compared to IL4-DC, IFN-DC were characterised by higher sensitivity to the chemical compounds studied here, such that all subsequent experiments with $\mathrm{CpG}-\mathrm{ODN}$ were conducted using IFN-DC cell cultures.

To ascertain that the enhancement of allostimulatory DC activity was indeed attributable to terminal DC maturation, 
Table 4. Phenotype of IFN-DCs generated with different stimuli

\begin{tabular}{|c|c|c|c|c|c|}
\hline IFN-DC cultures & $\mathrm{CD} 14^{+}, \%$ & $\mathrm{CD} 83^{+}, \%$ & $\mathrm{CD}^{2} 6^{+}, \%$ & HLA-DR ${ }^{+}, \%$ & $\mathrm{HLA}-\mathrm{DR}^{+} \mathrm{OX} 40 \mathrm{~L}^{+}, \%$ \\
\hline $\mathrm{DC}_{0}$ (control) & $41.5(38-47)$ & $11.5(9-16)$ & $72.0(44-87)$ & $83.5(76-87)$ & $8.0(5.5-17.0)$ \\
\hline$D C_{\mathrm{LPS}}$ & $31.5(26-37) \downarrow^{* *}$ & $33.0(16-44) \uparrow^{*}$ & $80.5(77-91)$ & $86.5(81-90)$ & $15.0(7.8-24.0) \uparrow^{*}$ \\
\hline $\mathrm{DC}_{\mathrm{dsDNA}}$ & $30.0(27-33) \downarrow^{* *}$ & $20.0(11-38)$ & $84.0(81-88)$ & $81.5(79-91)$ & $9.3(5.4-24.0)$ \\
\hline $\mathrm{DC}_{\mathrm{AB}}$ & $30.5(23-34) \downarrow^{* *}$ & $22.5(12-43) \uparrow^{*}$ & $81.0(79-85)$ & $83.0(76-88)$ & $9.0(6.3-20.0)$ \\
\hline $\mathrm{DC}_{\mathrm{SD}-101}$ & $37.0(32-38)$ & $20.0(14-35) \uparrow^{*}$ & $82.5(77-86)$ & $81.0(69-92)$ & $7.0(6.0-27.0)$ \\
\hline $\mathrm{DC}_{\mathrm{SD}-101 \mathrm{M}}$ & $33.5(32-36) \downarrow^{* *}$ & $18.5(16-42) \uparrow^{*}$ & $79.0(67-81)$ & $82.0(76-91)$ & $12.5(7.3-27.0) \uparrow^{*}$ \\
\hline
\end{tabular}

Note. The data of three independent experiments ( $n=7 ; \%$ of positive IFN-DC) are presented as median and interquartile range (in brackets); Stimuli: LPS $10 \mu \mathrm{g} / \mathrm{ml}$; dsDNA $5 \mu \mathrm{g} / \mathrm{ml}$; AB $2 \mathrm{ng} / \mathrm{ml}$; SD-101 and SD-101M $1 \mu \mathrm{g} / \mathrm{ml} .{ }^{*} p<0.05 ;{ }^{* *} p<0.01$ - vs control (Wilcoxon's W test).
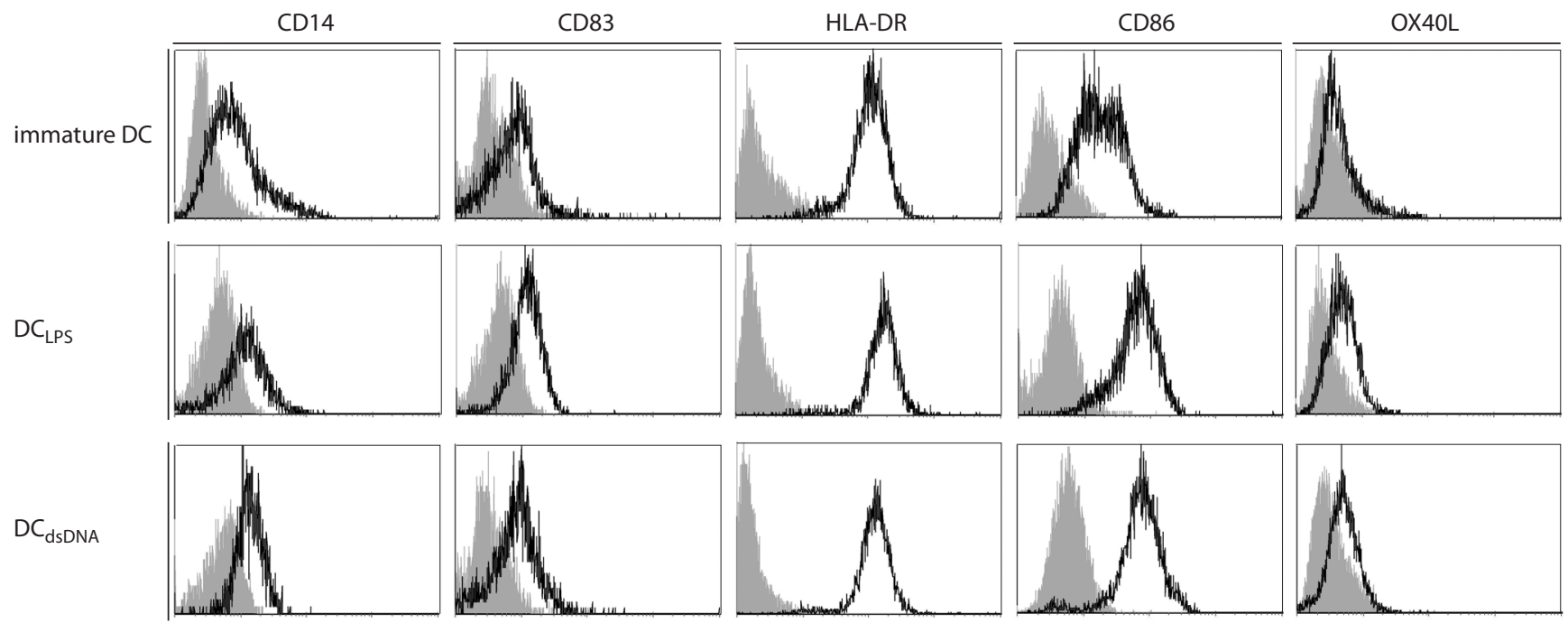

$\mathrm{DC}_{\mathrm{AB}}$
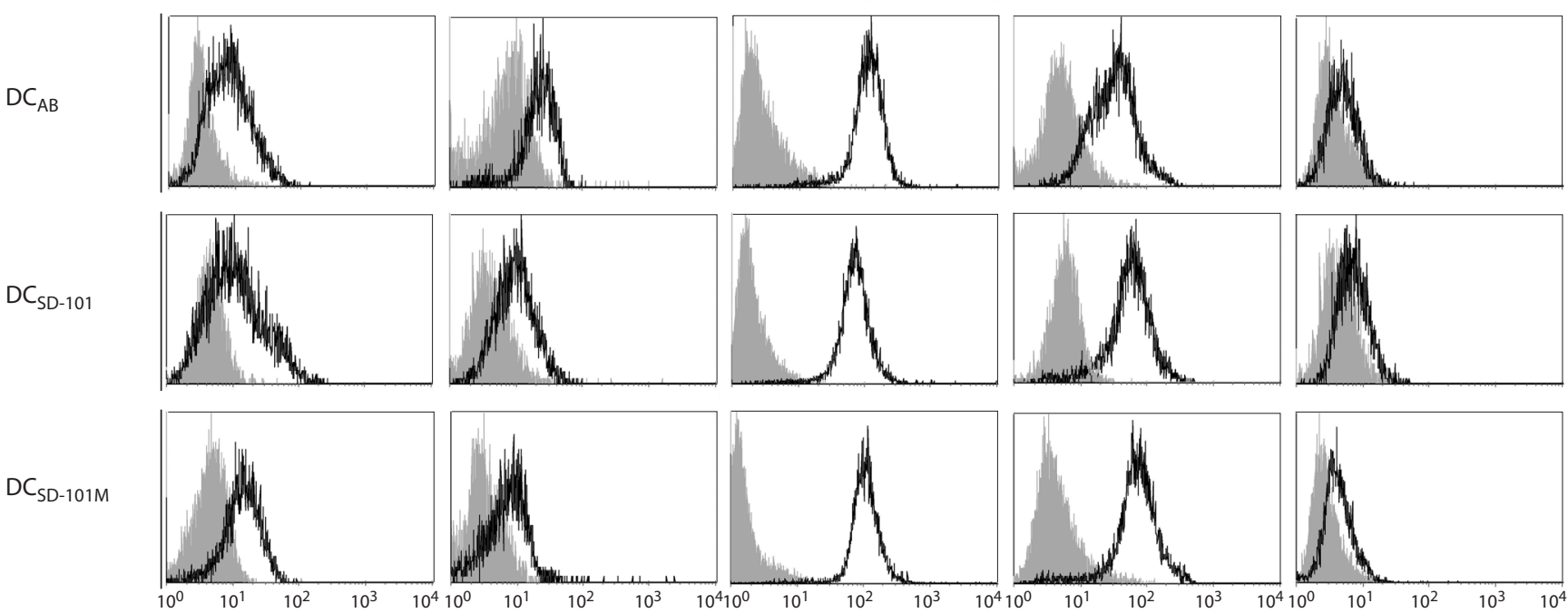

Fig. 2. Phenotypic analysis of IFN-DC generated in vitro with different stimuli.

Immature IFN-DC were cultured with different stimuli for $24 \mathrm{~h}$ followed by flow cytometry analysis of surface molecules CD14, CD83, HLA-DR, CD86, OX40L. Figures show flow cytometry histograms representing the expression of studied markers (bold-line histograms) and matched isotype controls (gray-filled histograms).

we studied immunophenotypic changes occurring in IFN-DC cultivated in the presence of CpG-ODN, as compared to other PAMP and DAMP activators. In this series of experiments, we selected CpG-ODN SD-101 and its $\mu$-analogue SD-101M that showed most pronounced stimulatory activity in previous experiments. Table 4 and Figure 2 indicate that $\mathrm{CpG}-\mathrm{ODN}$ derivatives studied exerted a clear maturation effect on DC analogous to that observed in the presence of LPS. This maturation effect manifested itself in: (i) reduced percentages of $\mathrm{CD}_{14}{ }^{+}$monocyte precursors, (ii) increased proportion of 
Table 5. TNF- $\alpha$ and IFN- $\gamma$ concentration in IFN-DC cultures generated with different stimuli

\begin{tabular}{|c|c|c|c|}
\hline IFN-DC cultures & & TNF-a & $\mathrm{IFN}-\gamma$ \\
\hline Immature DC (control) & $\mathrm{pg} / \mathrm{mL}$ & $290(206-500)$ & $130(90-190)$ \\
\hline \multirow[t]{2}{*}{$D C_{\text {LPS }}$} & $\mathrm{pg} / \mathrm{mL}$ & $1680(840-1790)^{* *}$ & $225(145-385)^{* *}$ \\
\hline & $\mathrm{FI}$ & $3.7(1.4-8.4)$ & $1.6(1.3-2.0)$ \\
\hline \multirow[t]{2}{*}{$D C_{d s D N A}$} & $\mathrm{pg} / \mathrm{mL}$ & $785(264-1250)$ & $250(190-400)^{*}$ \\
\hline & $\mathrm{FI}$ & $1.4(0.9-2.7)$ & $1.4(1.1-2.0)$ \\
\hline \multirow[t]{2}{*}{$D C_{A B}$} & $\mathrm{pg} / \mathrm{mL}$ & $240(145-670)$ & $240(185-460)^{*}$ \\
\hline & $\mathrm{FI}$ & $0.9(0.8-1.1)$ & $1.2(1.1-1.9)$ \\
\hline \multirow[t]{2}{*}{$D C_{S D-101}$} & $\mathrm{pg} / \mathrm{mL}$ & $220(70-490)$ & $230(160-460)^{*}$ \\
\hline & $\mathrm{FI}$ & $0.7(0.3-1.9)$ & $1.71(1.5-2.1)$ \\
\hline \multirow[t]{2}{*}{$\mathrm{DC}_{\mathrm{SD}-101 \mathrm{M}}$} & $\mathrm{pg} / \mathrm{mL}$ & $215(120-740)$ & $230(180-380)^{*}$ \\
\hline & $\mathrm{FI}$ & $1.0(0.6-1.9)$ & $1.74(1.3-2.1)$ \\
\hline
\end{tabular}

Note. The data of six independent experiments $(n=13)$ are presented as median and interquartile range (in brackets); ${ }^{*} p<0.05 ;{ }^{* *} p<0.01-$ vs control (Wilcoxon's W test).

mature $\mathrm{CD} 83^{+} \mathrm{DC}$, and (iii) a clear upward trend for DC expressing a co-stimulatory molecule CD86 ( $p=0.07-0.11)$. Similar effects were documented in the presence of dsDNA and $\mathrm{AB}$. Interestingly, LPS treatment also significantly enhanced percentages of OX40L-positive DC from 8 to $15 \%$, which corresponds to $45 \%$ cumulative gain in this particular cell population. The effect of CpG-ODN containing mesylphosphoramidate internucleotide linkages (SD-101M) on OX40L expression was comparable to that observed in the presence of LPS, with percentages of OX $40 \mathrm{~L}+\mathrm{DC}$ increasing by $39 \%$ (up to $12.5 \%, p=0.0282$ ). Meanwhile, the effects of dsDNA, AB and SD-101 with thiophosphate internucleotide groups on OX40L expression were less pronounced and did not reach statistically significant levels.

In the last experiments we assessed the effects of CpG-ODN SD-101 derivative and its $\mu$-analogue SD-101M on TNF- $\alpha$ and IFN- $\gamma$ production in 5-day IFN-DC cultures (Table 5) because DC maturation is known to be accompanied by the enhancement of cytokines with pro-inflammatory and Th1-stimulatory activity. As compared to immature cells, LPS-activated DC produced higher levels of TNF- $\alpha$ and IFN- $\gamma(p<0.01)$. CpG-ODN derivatives SD-101 and SD-101M, as well as AB did not affect TNF- $\alpha$ production, while dsDNA treatment increased TNF- $\alpha$ concentrations in DC cultures by $43 \%$, although this effect was not statistically significant.

Interestingly, SD-101 and SD-101M significantly enhanced the ability of IFN-DC to produce IFN- $\gamma$ by 71 and $74 \%$, respectively $(p<0.05)$, which was commensurate with LPSmediated effects. Other DAMP activators (dsDNA and AB) also enhanced IFN- $\gamma$ production by DC.

\section{Discussion}

Data obtained in this study demonstrated intracellular TLR-9 expression in monocyte-derived IFN-DC or IL4-DC. Both DC populations studied here were characterised by sensitivity to $\mathrm{CpG-ODN}$ class $\mathrm{C}$ derivatives, which enhanced DC-dependent ability to stimulate $\mathrm{T}$ cell proliferation in alloMLR via up-regulation of CD83 differentiation antigen and
OX40L/CD86 co-stimulatory molecule expression, as well as increased IFN- $\gamma$ production by DC. Interestingly, IFN-DC possessed higher sensitivity to the stimulatory effects of CpG-ODN, as compared to IL4-DC.

TLR-9 expression and CpG-ODN sensitivity have been shown to be characteristic of both plasmacytoid and myeloid DC in murine experimental systems (Behboudi et al., 2000; Iwasaki, Medzhitov, 2004). Early human studies were based on RT-PCR analysis and demonstrated constitutive TLR-9 mRNA expression only in plasmacytoid (but not myeloid or monocyte-derived) DC (Bauer et al., 2001; Krug et al., 2001; Rothenfusser et al., 2002). Nevertheless, in later studies H. Tada et al. discovered TLR-9 mRNA in monocyte-derived DC (mo-DC) and demonstrated enhancement of IL-12p70 and IFN- $\gamma$ production in mo-DC cell cultures in response to CpG-ODN stimulation (Tada et al., 2005). In line with these observations, V. Hoene et al. identified TLR-9 protein in mo-DC, which notably was present in the same amounts as in plasmacytoid DC. These authors showed that CpG-ODN class A derivatives stimulated DC maturation and enhanced the ability of DC to stimulate proliferation of allogeneic T cells (Hoene et al., 2006). In this respect, our results constitute another confirmation of human myeloid DC sensitivity to the stimulatory effects exerted by $\mathrm{CpG}-\mathrm{ODN}$. In view of the fact that the majority of DC present in tumour microenvironment are of monocyte origin (Veglia, Gabrilovich, 2017), our results imply high clinical potential for CpG-ODN in DC activation protocols, such as those employed in anti-cancer immunotherapy.

Importantly, our study was also first to compare classical thiophosphate $\mathrm{CpG}-\mathrm{ODN}$ class $\mathrm{C}$ derivatives (SD-101 and D-SL03) with their original analogues containing mesyl-phosphoramidate ( $\mu$-modified) internucleotide groups (SD-101M and D-SL03M). CpG-ODN class C derivatives combine immunomodulating properties characteristic of $\mathrm{CpG}-\mathrm{ODN}$ class A and B derivatives (Marshall et al., 2005) and also possess pronounced immunostimulatory and anti-cancer effects (Li et al., 2020). For instance, L. Yang et al. demonstrated 
distinct stimulatory activity of CpG-ODN D-SL03 derivative, which was able to: (i) activate human B cells, NK cells and $\mathrm{T}$ cells in vitro; (ii) intensity the expression of CD80, CD86 and HLA-DR in mononuclear cell cultures, and (iii) furnish anti-cancer effects in a murine model of breast cancer in vivo (Yang et al., 2013). As far as CpG-ODN SD-101 is concerned, this derivative demonstrated immunostimulatory and anticancer effects during local anti-cancer immunotherapy in patients (Levy et al., 2016; Li et al., 2020). Based on the aforementioned $\mathrm{CpG}$-ODN derivatives, this study was first to synthesise modified analogues SD-101M and D-SL03M with mesyl-phosphoramidate internucleotide groups, which were shown in our previous reports to be more stable to enzymatic cleavage (Miroshnichenko et al., 2019).

A comparison analysis of CpG-ODN derivatives performed here showed that $\mu$-modified analogues were superior in enhancing allostimulatory DC activity, as compared to CpG-ODN containing thiophosphate internucleotide groups. Moreover, it was the particular $\mu$-type SD-101 derivative (SD-101M) that was found to enhance OX40L [an important co-stimulatory molecule regulating the intensity of $\mathrm{T}$ cell proliferation in allo-MLR (Ukyo et al., 2003)] expression in IFN-DC population, i.e. displayed properties characteristic of LPS.

It should be stressed that TLR-4-specific ligand LPS constitutes a powerful DC maturation activator, which is widely used in various in vitro settings as a positive control. TLR-4mediated signalling is known to increase a downstream augmentation of co-stimulatory molecule expression, pro-inflammatory cytokine production, DC-mediated stimulatory activity with respect to allogeneic $\mathrm{T}$ cell proliferation, and Th1-dependent responses (Cehim, Chies, 2019), thus supporting full-fledged immunological functionality of activated DC. Interestingly, V. Hoene et al. showed that stimulatory effect of D19 (CpG-ODN class A compound) on maturation and allogeneic activity of DC was lower than LPS (Hoene et al., 2006). Meanwhile, this study showed that SD-101M activity was in fact higher than LPS, with SD-101, D-SL03 and D-SL03M-associated activity being comparable to that of LPS. Enhancement of IFN- $\gamma$ production in response to CpG-ODN (SD-101 and SD-101M) treatments was also commensurate to LPS.

It should be mentioned that we compared CpG-ODN class $\mathrm{C}$ derivatives not only with LPS, but also with such DAMP activators as human dsDNA and azoximer bromide. Stimulatory effects of SD-101M on DC maturation and allostimulatory activity was found to be commensurate with dsDNA and AB, which complements our previous studies that showed stimulatory effects of dsDNA on DC maturation and allostimulatory activity (Alyamkina et al., 2010; Orishchenko et al., 2013). However, this study also described for the first time an ability of an AB-based polymeric adjuvant developed in Russia to stimulate in vitro maturation of DC derived from monocytes in the presence of IL-4 or IFN- $\alpha$, as well as to enhance DC allostimulatory activity. These findings provide an important experimental support for the effective clinical application of this adjuvant in anti-viral vaccine formulations. Of note, SD-101M outcompeted for a number of parameters (for example, induction of OX40L expression and IFN- $\gamma$ production) dsDNA and $\mathrm{AB}$.

\section{Conclusion}

Taken together, data obtained in this study demonstrated pronounced stimulatory effects of $\mathrm{CpG}-\mathrm{ODN}$ class $\mathrm{C}$ derivatives (SD-101 and D-SL03) on human myeloid DC, which were commensurable to that displayed by PAMP (LPS) and DAMP (dsDNA and AB) activators, while the effects of a mesyl-phosphoramidate ( $\mu$-) analogue SD-101M were even stronger. Further studies in murine experimental models are needed to analyze the efficacy of the $\mu$-modified CpG-ODN (SD-101M with mesyl-phosphoramidate internucleotide groups) in anti-cancer immunotherapy.

\section{References}

Alyamkina E.A., Leplina O.Yu., Sakhno L.V., Chernykh E.R., Ostanin A.A., Efremov Ya.R., Shilov A.G., Orishchenko K.E., Likhacheva A.S., Dolgova E.V., Nikolin V.P., Popova N.A., Zagrebelniy S.N., Bogachev S.S., Shurdov M.A. Effect of double-stranded DNA on maturation of dendritic cells in vitro. Cell. Immunol. 2010;266(1): 46-51. DOI 10.1016/j.cellimm.2010.08.011.

Banchereau J., Briere F., Caux C., Davoust J., Lebecque S., Liu Y.J., Palendran B., Palucka K. Immunobiology of dendritic cells. Annu. Rev. Immunol. 2000;18:767-811. DOI 10.1146/annurev.immunol. 18.1.767.

Bauer S., Kirschning C.J., Hacker H., Redecke V., Hausmann S., Akira S., Wagner H., Lipfordet G.B. Human TLR9 confers responsiveness to bacterial DNA via species-specific CpG motif recognition. Proc. Natl. Acad. Sci. USA. 2001;98(16):9237-9242. DOI 10.1073/ pnas. 161293498 .

Behboudi S., Chao D., Klenerman P., Austyn J. The effects of DNA containing CpG motif on dendritic cells. Immunology. 2000;99(3): 361-366. DOI 10.1046/j.1365-2567.2000.00979.x.

Cehim G., Chies J.A.B. In vitro generation of human monocyte-derived dendritic cells methodological aspects in a comprehensive review. An. Acad. Bras. Ciênc. 2019;91:e20190310. DOI 10.1590/00013765201920190310.

Chelobanov B.P., Burakova E.A., Prokhorova D.V., Fokina A.A., Stetsenko D.A. New oligodeoxynucleotide derivatives containing $N$-(methanesulfonyl)-phosphoramidate (mesyl phosphoramidate) internucleotide group. Russ. J. Bioorg. Chem. 2017;43(6):664-668. DOI 10.1134/S1068162017060024.

Dyakonova V.A., Dambaeva S.V., Pinegin B.V., Khaitov R.M. Study of interaction between the polyoxidonium immunomodulator and the human immune system cells. Inter. Immunopharm. 2004;4(13): 1615-1623. DOI 10.1016/j.intimp.2004.07.015.

Hoene V., Peiser M., Wanner R. Human monocyte-derived dendritic cells express TLR9 and react directly to the CpG-A oligonucleotide D19. J. Leuk. Biol. 2006;80(6):1328-1336. DOI 10.1189/jlb. 0106011.

Iwasaki A., Medzhitov R. Toll-like receptor control of the adaptive immune responses. Nat. Immunol. 2004;5(10):987-995. DOI 10.1038/ ni1112.

Jounai N., Kobiyama K., Takeshita F., Ishii K.J. Recognition of damage-associated molecular patterns related to nucleic acids during inflammation and vaccination. Front. Cell. Infect. Microbiol. 2013; 2:168. DOI 10.3389/fcimb.2012.00168

Kabanov V.A. From synthetic polyelectrolytes to polymer-subunit vaccines. Pure Appl. Chem. 2004;76(9):1659-1677. DOI 10.1351/pac 200476091659.

Kawasaki T., Kawai T. Toll-like receptor signaling pathways. Front. Immunol. 2014. DOI 10.3389/fimmu.2014.00461.

Krug A., Towarowski A., Britsch S., Rothenfusser S., Hornung V., Bals V., Giese T., Engelmann H., Endres S., Krieg A.M., Hartmann G. Toll-like receptor expression reveals CpG DNA as a unique microbial stimulus for plasmacytoid dendritic cells which synergizes with CD40 ligand to induce high amounts of IL-12. Eur. J. Immu- 
nol. 2001;31(10):3026-3037. DOI 10.1002/1521-4141(2001010)31: $10<3026$ ::aid-immu3026>3.0.co;2-h.

Levy R., Reagan P.M., Friedberg J.W., Bartlett N.L., Gordon L.I., Leung A., Peterkin J., Xing B., Coffman R., Janssen R., Candia A., Khodadoust M., Frank M.J., Long S.R., Czerwinski D.K., Chu M. SD-101, a novel class C CpG-oligodeoxynucleotide (ODN) toll-like receptor 9 (TLR9) agonist, given with low dose radiation for untreated low grade B-cell lymphoma: interim results of a phase $1 / 2$ trial. Blood. 2016;128(22):2974. DOI 10.1182/blood.V128.22.2974. 2974.

Li T., Wu J., Zhu S., Zang G., Li S., Lv X., Yue W., Qiao Y., Cui J., Shao Y., Zhang J., Liu Y.-J., Chen J. A novel C type CpG oligodeoxynucleotide exhibits immunostimulatory activity in vitro and enhances antitumor effect in vivo. Front. Pharmacol. 2020;11:8. DOI 10.3389/fphar.2020.00008.

Marshall J.D., Fearon K.L., Higgins D., Hessel E.M., Kanzler H., Abbate C., Yee P., Gregorio J., Cruz T.D., Lizcano J.O., Zolotorev A., McClure H.M., Brasky K.M., Murthy K.K., Coffman R.L., Nest G.V. Superior activity of the type C class of ISS in vitro and in vivo across multiple species. DNA Cell Biol. 2005;24(2):63-72. DOI 10.1089/dna.2005.24.63.

Miroshnichenko S.K., Patutina O.A., Burakova E.A., Chelobanov B.P., Fokina A.A., Vlassov V.V., Altman S., Zenkova M.A., Stetsenko D.A. Mesyl phosphoramidate antisense oligonucleotides as an alternative to phosphorothioates with improved biochemical and biological properties. Proc. Natl. Acad. Sci. USA. 2019;116(4): 1229-1234. DOI 10.1073/pnas.1813376116.

Orishchenko K.E., Ryzhikova S.L., Druzhinina Y.G., Ryabicheva T.G., Varaksin N.A., Alyamkina E.A., Dolgova E.V., Rogachev V.A., Proskurina A.S., Nikolin V.P., Popova N.A., Strunov A.A., Kiseleva E.V., Leplina O.Y., Ostanin A.A., Chernykh E.R., Sidorov S.V., Mayorov V.I., Bogachev S.S., Shurdov M.A. Effect of human double-stranded DNA preparation on the production of cytokines by dendritic cells and peripheral blood cells from relatively healthy donors. Cancer Ther. 2013;8:191-205.
Polovinkina V.S., Markov E.Yu. Structure and immune adjuvant properties of CpG-DNA. Meditsinskaya Immunologiya $=$ Medical Immunology (Russia). 2010;12(6):469-476. DOI 10.15789/1563-06252010-6-469-476. (in Russian)

Powell B.S., Andrianov A.K., Fusco P.C. Polyionic vaccine adjuvants: another look at aluminum salts and polyelectrolytes. Clin. Exp. Vaccine Res. 2015;4(1):23-45. DOI 10.7774/cevr.2015.4.1.23.

Rothenfusser S., Tuma E., Endres S., Hartmann G. Plasmacytoid dendritic cells: the key to CpG. Hum. Immunol. 2002;63(12):1111-1119. DOI 10.1016/s0198-8859(02)00749-8.

Scheiermann J., Klinman D.M. Clinical evaluation of CpG oligonucleotides as adjuvants for vaccines targeting infectious diseases and cancer. Vaccine. 2014;32(48):6377-6389. DOI 10.1016/j.vaccine. 2014.06.065.

Shirota H., Klinman D.M. Recent progress concerning CpG DNA and its use as a vaccine adjuvant. Expert Rev. Vaccines. 2014;13(2):299312. DOI 10.1586/14760584.2014.863715.

Shirota H., Tross D., Klinman D.M. CpG oligonucleotides as cancer vaccine adjuvants. Vaccines (Basel). 2015;3(2):390-407. DOI 10.3390/vaccines 3020390 .

Tada H., Aiba S., Shibata K., Ohteki T., Takada H. Synergistic effect of Nod1 and Nod2 agonists with toll-like receptor agonists on human dendritic cells to generate interleukin-12 and T helper type 1 cells. Infect. Immun. 2005;73(12):7967-7976. DOI 10.1128/IAI.73.12. 7967-7976.2005.

Ukyo N., Hori T., Yanagita S., Ishikawa T., Uchiyama T. Costimulation through OX40 is crucial for induction of an alloreactive human T-cell response. Immunology. 2003;109(2):226-231. DOI 10.1046/j.13652567.2003.01648.x.

Veglia F., Gabrilovich D.I. Dendritic cells in cancer: the role revisited. Curr. Opin. Immunol. 2017;45:43-51. DOI 10.1016/j.coi.2017.01.002.

Yang L., Wu X., Wan M., Yu Y., Yu Y., Wang L. CpG oligodeoxynucleotides with double stem-loops show strong immunostimulatory activity. Int. Immunopharmacol. 2013;15(1):89-96. DOI 10.1016/ j.intimp.2012.10.020.

\section{ORCID ID}

A.A. Ostanin orcid.org/0000-0001-6895-938X

O.Y. Leplina orcid.org/0000-0003-3169-8643

E.A. Burakova orcid.org/000-0001-6644-5959

T.V. Tyrinova orcid.org/0000-0002-7987-2017

A.A. Fokina orcid.org/0000-0001-5692-2483

A.S. Proskurina orcid.org/0000-0002-7650-4331

S.S. Bogachev orcid.org/0000-0002-2019-9382

D.A. Stetsenko orcid.org/0000-0002-5215-5704

E.R. Chernykh orcid.org/0000-0003-2346-6279

Acknowledgements. This work was supported by the Russian Foundation for Basic Research, project 18-29-09045_mk and partly by the Ministry of Science and Higher Education of the Russian Federation (project No. FSUS-2020-0035 to Novosibirsk State University). The authors are grateful to A. Delvig for providing language help during manuscript writing.

Conflict of interest. The authors declare no conflict of interest.

Recieved May 26, 2020. Revised August 05, 2020. Accepted August 11, 2020. 